\title{
DA ACÇÃO DO ACIDO TARTARICO SOBRE O VIRUS VACCINICO
}

* (Communicação feita á Sociedade de Medicina e Cirurgia de S. Paulo e ainda não publicada)

\author{
PELO DR. ALEX. M. PEDROSO
}

Director do Laboratorio Anatomo-pathologico da Santa Casa de S. Paulo; Prof. de Microbiologia na Faculdade de Medicina e Cirurgia ide S. Paulo.

Para aquelles que só conhecem a lympha ou a polpa vaceinica atrarez do conteudo dos pequenos tubos capillares que o Serviço Sanitario distribue ás mancheias pelo nosso e por outros Estados da União Brasileira, parecerá que a fabricação desse producto biologico, de tão util e vasto uso, apenas exige uma experiencia limitada e um preparo technico muito resumido da parte de quemi os manipula.

Isso é porém simples supposição. A verdade é muito outra, principalmente em se tratando da producção em paiz de clima quente como o nosso, em que, alem de outras difficuldades, temos de nos haver com èsse factor importante - a temperatura - aqui em grande parte do anno, propricia ao rapido esgotamento da actividade do virus existente na polpa vacinica.

Até nos paizes onde uma grande parte do anno a temperatura é baixa, favorecendo a conservação do virus, os laboratorios, quer particulares quer dos governos, são, de quando em vez, sujeitos a crise ou a carencia de virus vacinico por motivos que nem sempre se podem verificar ou explicar.

Ainda não ha muito, nos Estados Unidos, uma das grandes e mais acreditadas firmas de productos biologicos, a M. ., diante da pouca virulencia de sua vaccina, mandou vir do Japão uma semente, que sabia muito estavel e activa, talvez a melhor existente.

A semente era de facto muito boa, porém a sua introducção custou caro ao paiz, pois a polpa trazia alem do virus vaccinico o da febre aphtosa.

Nos bezerros vaccinados desenvolveu-se a febre aphtosa, tempos depois da collecta da vaccina e quando elles já haviam sido devolvidos ás hendades de onde provinham. A febre aphtosa espalhou-se com a rapidez a diversas fazendas e, não fora a energia de acção do governo, alliada á iniciativa dos criadores, a febre aphtosa teria se propagado de tal forma a se tornar o flagello, que periodicamente vemos entre nós.

Esta campanha que custou milhões e milhões de dollars ao paiz e aos criadores no sacrificio de rebanhos inteiros affectados ou Euspeitos, erradicou por completo a molestia de onde ella tinha conseguido se alojar. 
Em o nosso Instituto Vaccinogenico a crise da vaccina tem se manifestado de vez em quando e os Directores do Serviço Sanitario, conhecedores deste acontecimento normal, que periodicamente visitam os Institutos de Vaccina, vem sempre protegendo com a sua autoridade essas epochas de depressão verificada na efficacia da vaccina, para impedir que sua publicidade venha 3 produzir o descredito injusto de um Instituto, por todos os titulos digno de nosso carinho e orgulho.

Ha annos atraz tive opportunidade de trabalhar como Assistente do Instituto Vaccinogenico, durante o tempo em que o nosso pranteado amigo Dr. Arnaldo Vieira de Carvalho representava S. Paulo na Exposição de Hygiene de Dresden.

Nessa occasião possuia o Instituto, alem da semente antiga, uma nova, retirada de uma vacca que apresentou a molestia aqui em S. Paulo. Esta vaccina foi sempre muito fraca e não durou muito no Instituto.

A semente, então em uso, apresentava logo que comecei a trảathar no Instituto, certas anormalidades, que bastante nos preoccupavam, principalmente porque na epocha grassava com intensidade, em muitos pontos do interior, uma epidemia de variola, a qual pela sua benignidade e invasão rapida se quiz considerar como uma rova molestia.

A nossa vaccina nessa occasião prodizia por vezes rəacções muito violentas e em outras a porcentagem de vaccinações positivas era muito baixa.

Verifiquei que uma das causas da pouca efficacia da nossa vaccina era a reacção dos tubos capillares, $\in m$ vez de neutra como se esperava, decididamente alcalina, o que vinha alterar rapidamente a polpa. enfraquecendo o virus ou destruindo-o, por completo, dentro de um espaço de tempo relativamente curto.

Comc os tubos capillares são de calibre differente, tive o cuidado de examinar a polpa vaccinica, guardada em tubos de diversos calibres e notei que:

1) a polpa, guardada nos tubos de menor calibre, se tornava mais rapidamente alcalina e perdia a sua efficiencia mais depressa;

2) a parte central da polpa, guardarla em tubos de calibre maior, se conservava neutra por algum tempo e activa, emquanto a parte peripherica era alcalina e inactiva.

A alcalinidade era verificada como o papel tournesol e a efficacia das vaccinas em bezerros.

Isto explicava em parte a inacção das vaccinas.

Mas os pedidos de polpa se succediam com tal frequercia que o espaço de tempo entre o entubamento da polpa e seu uso, não 
cra sufficiente para permittir que a alcalinidade attingisse o ponto necessario para a destruição do virus.

Alem disso até as vaccinações com os frascos collectivos, verificadamente neatros não davam scmpre o resultado desejado.

Pareceu-me porem. que a razão capital do enfraquecimento da vaccina estava na perturbação de sua sahida.

Durante os mezes frios a glycerina, usada para a purificação da poipa, age mais lentamente sobre as bacterias, levando portanto mais tempo para expurgar as sementes das bacterias normalmonte existentes, de modo que com a grande sahida de polpa, era as vezes necessario usar-se como semente polpa que ainda não estava bem purificada, produzindo um circulo vicioso de modo a enfraquecer o virus. dada a concorrencia do germem.

O Dr. Medeiros conseguiu, depois de algumas tentativas, purificar novamente a vaccina, passando-a atravez de coelhos e obteve de novo o virus activo, produzindo pustulas typicas.

Vaccinar é uma operação que todo o medico é canaz de fazer. depois de ter visto a sua execução uma vez; porem o que nem todos sabem, ou antes, o que quasi todos ignoram são os cuidados que se deve ter com a polpa vaccinica.

Não é raro ver-se $11 \mathrm{~m}$ inspector, com umas dezenas de tubos no bolso, aconselhar a vaccinação, porque a vaccina que elle tem é da boa, sem cogitar se o tempo e o calor a enfraqueceu; assim como não é raro ver-se o inspector accusado de inepto na execução de uma das operações mais banaes da medicina, sem que tenha culpa alguma do insuccesso.

A conselho do Dr. Carini tive o cuidado de verificar, por processo por elle usado em Berne muitas das polpas que deixou o Instituto Vaccinogenico para serem usadas pelos inspectores e tive opportunidade de ver, como elle já suppunha, que nem sempre a actividade da polpa era sufficiente para resistir mais do que alguns dias, antes de se tornar completamente inactiva e que, algumas. raras porem, sahiam do Instituto já sem poder vaccinante algum.

Ha no Instituto certas normas cuja utilidade nunca consegui verificar, como o uso da tuberculina, a numeração das vaccinas, etc.

Esta ultima practica teria sua razão de ser se fosse usada para 9. verificação systematica das vaccinas a deixarem o Instituto, ג para avisar o inspector da sua inefficacia, mas nunca, como meio de defesa do Instituto, como tem sido feita.

Tomada duas parcelas de vaccina e collocada uma nas melhores condições possiveis de conservacão, como deve existir no Instituto. $\therefore$ outra enviada á Directoria dc Serviço Sanitario, que dẹois de alguns dias a remette ao Prefeito de alguma localidade do Interior ou ao inspector, é claro que, apezar de terem o mesmo numero, as 
vaccinas são completamente differentes quanto a sua efficacia depois de alguns dias.

O medico que a usar não deverá ser incriminado de inhabil, se não obtiver resultados positivos, embora a semente deixada no Instituto dê cento por cento de resultados positivos.

A razão é simples e conhecida.

Noguchi, em 1918, verificou que o virus vaccinico puro morre tanto mais rapidamente quanto maior fôr a percentagem de glycerina em que esteja suspenso e que, nas mesmas proporções de glycerina, morre mais depressa quando collocados a $37^{\circ} \mathrm{C}$. do que a 18 C. e nesta temperatura dura menos tempo que a 4. C. A vaccina quer o frio para a sua conservação.

Tendo em vista as difficuldades que acima apontei, procurei, então, investigar um lado da questão estudando um methodo que permittisse a conservação da vaccina em outros meios que não fosse a glycerina e com uma ligeira acidez, afim de neutralisar a alcalinidade dos tubos, visto ser este, geralmente, o defeito. Comquanto não conseguisse verificar definitivamente a sua utilidade o resultado de minhas experiencias foi tão animador que julgo digno de registro não só o principio em que se fundaram. como o seu protocollo.

No preparo de meios de cultura para cogumellos é aconselhavel $o$ uso de quantidade minima de acido tartarico para impedir o desenvolvimento de bacterias. Usando deste mesmo acido procurei verificar a sua acção não sómente sobre o desenvolvim’nto də bacterias na vaccína como tambem sobre o proprio virus vaccinico.

O protocollo da experiencia é o seguinte:

Polpa para semente - Vitello $\mathrm{N}^{\circ} 2.209$.

Setembro, 7, 1911. Juntaram-se 15,0 grms. de glycerina á 15,0 grms. de polpa, e tudo foi guardado na galeria de $10^{\circ} 14^{\circ} \mathrm{C}$. até o dia 9 do mesmo mez.

Setembro 9. A polpa e a glycerina foram trituradas em um gral.

Collocaram-se 4,0 cc. desta polpa-glycerinada, contedo 2 cc. de polpa para 2 cc. de glycerina, em cada tubo (em numero de 6) e juntaram-se 6,0 cc. de diversas proporções de acido tartarico do modo seguinte:

$\begin{array}{ccccc}\text { Tubos } & \text { Polpa-glycerina } & \text { Acido tartarico } & \text { por cento } \\ \text { I } & 4,0 \mathrm{cc} & 0 & 0 & \\ \text { II } & 4,0 \mathrm{cc} & 1 / 60 & 1,0 & \% \\ \text { III } & 4,0 \mathrm{cc} . & 1 / 120 & 0,5 & \% \\ \text { IV } & 4,0 \mathrm{cc} . & 1 / 600 & 0,1 & \% \\ \text { V } & 4,0 \mathrm{cc} . & 1 / 1200 & 0.05 & \% \\ \text { VI } & 4,0 \mathrm{cc} & 1 / 6000 & 0,01 \%\end{array}$


Deixei os tubos a temperatura ambiente e em 12 de Setembro retirei duas gottas de cada tubo, que foram semeadas em geloses.imples.

Setembro 13 ( $24 \mathrm{hrs}$. depois) verifiquei a seguinte contagem:

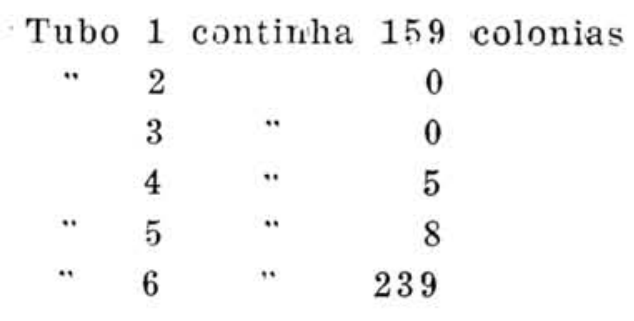

Donde se vê que o acido tartarico na proporção de $1 \%$ e $0,5 \%$ impediu por completo o desenvolvimento das bacterias existentes nessa polpa vaccinada, causando provalvemente a morte, das hacterias.

Nas proporções de $0,1 \%$ e $0,05 \%$ elle impede o desenvolvimento da maioria das bacterias ahi existentes e quando existente em $0,01 \%$ a sua acção sobre as bacterias é menor do que a da glycerina a $50 \%$.

Isto quanto á acção sobre as bacterias.

A acção do acido tartarico naquellas varias porcentagens sobre o virus vaccinico foi verificada do seguinte modo:

Setembro 18 (isto é, 9 dias após a mistura) vaccinei um bezerro com o material de cada tubo, separando as diversas incisões inoculadas por outras não inoculadas (como testemunhas) tive o seguinte resultado:

Dia 20 (ou 2 dias após a vaccinação)

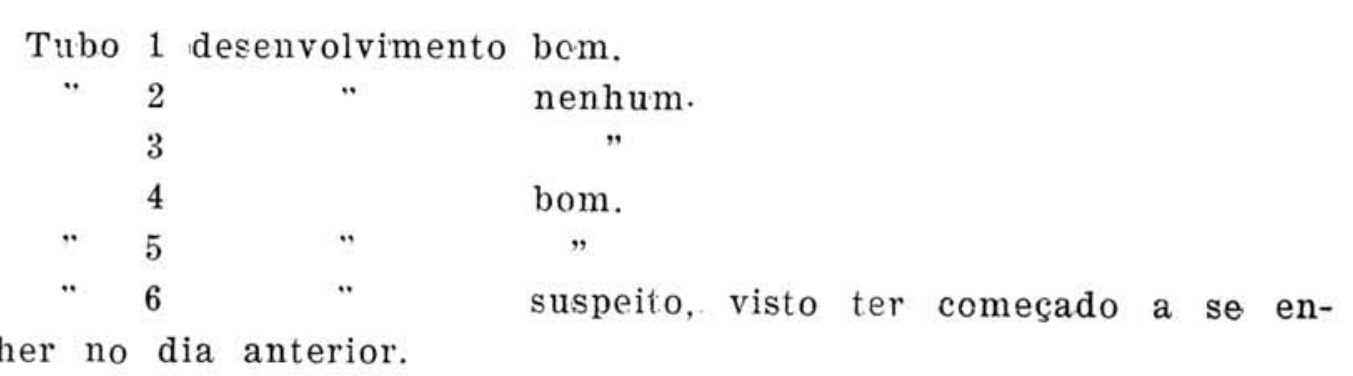

A incisão testemunha entre 5 e 6 desenvolveu vaccina.

Dessa experiencia se vê que na proporcão de $1 \%$ e $0,5 \%$, o acido tartarico destroe, nas condições expostas, em. 9 dias, o virus vaccinico; na porcentagem 0,1 em diante, a sua acção sobre o virus foi nulla. 
Com a mistura do conteudo dos tubos 4 e 5 fiz diversas vaccinações que foram positivas até cerca de um mez, depois do preparo da vaccina.

Tornando publicas estas minhas experiencias, não pretendo com isso apresentar conclusões difinitivas.

O resultado animador obtido nessas experiencias preliminares indica que estas investigações devem ser continuadas, pcis é possivel que, pelo processo que ensaiei se encontre uma solução para a conservação da vaccina. 